\title{
Design, Synthesis, in vitro Antiproliferative Activity, Binding Modeling of 1,2,4,-Triazoles as New Anti-Breast Cancer Agents
}

\section{Murat Genc, ${ }^{1, *}$ Zuhal Karagoz Genc, ${ }^{2}$ Suat Tekin, ${ }^{3}$ Suleyman Sandal, ${ }^{3}$ Muhammad Sirajuddin, ${ }^{4}$ Taibi Ben Hadda ${ }^{5}$ and Memet Sekerci ${ }^{6}$}

\author{
${ }^{1}$ Faculty of Science and Arts, Department of Chemistry, Adiyaman University, Adiyaman 02040, Turkey. \\ ${ }^{2}$ Faculty of Engineering, Department of Materials and Metallurgy Engineering, Adiyaman University, \\ Adiyaman-02040, Turkey. \\ ${ }^{3}$ Faculty of Medicine, Department of Physiology, Inonu University, 44280, Malatya, Turkey \\ ${ }^{4}$ Department of Chemistry, COMSATS Institute of Information Technology, Abbottabad-22060, Pakistan \\ ${ }^{5}$ Laboratoire Chimie Matériaux, FSO, Université Mohammed 1ER, Oujda-60000, Morocco \\ ${ }^{6}$ Faculty of Science, Department of Chemistry, Firat University, Elazig 02040, Turkey. \\ * Corresponding author: E-mail: mgenc23@gmail.com \\ Tel: +904162233800/4048; Fax: +904162233807
}

Received: 03-14-2016

\begin{abstract}
This article demonstrates the synthesis of 1,2,4-triazole derivatives and their applications in medicine particularly as anti-breast cancer agents which is a major issue of the present. The synthesized compounds were characterized by elemental analysis, FT-IR and NMR. DFT was used to study the quantum chemical calculations of geometries and vibrational wave numbers of 3-hydroxynaphthyl and $p$-tolyl substituted 1,2,4-triazoles in the ground state. The scaled harmonic vibrational frequencies obtained from the DFT method were compared with those of the FT-IR spectra and found good agreement. The synthesized 1,2,4-triazole-naphthyl hybrids were screened for the anticancer activity against MCF-7 breast cancer lines. Among them compounds 3 and 7 showed broad spectrum anticancer activity with $\mathrm{IC}_{50}$ values 9.7 $\mu \mathrm{M}$ and $7.10 \mu \mathrm{M}$, respectively and their activity is comparable to that of the standard drugs. The molecular model for binding between the compounds (1-8) and the active site of BRCA2 was obtained on the basis of the computational docking results and the structure-activity relationship.
\end{abstract}

Keywords: 1,2,4- triazoles; Docking; DFT; POM Analysis; Breast cancer

\section{Introduction}

Triazole based compounds have a wide range of applications in analytical, industrial and medicinal chemistry. Their important biological activities include antifungal, ${ }^{1-6}$ antibacterial, ${ }^{7}$ anticancer ${ }^{8}$ and antiviral, ${ }^{9-11} \mathrm{H} 1 / \mathrm{H} 2$ histamine receptor blockers, cholinesterase active agents, central nervous system (CNS) stimulants, antianxiety and sedatives. ${ }^{12-13}$ Antimycotic, fluconazole, itraconazole, ravuconazole and variconazole are therapeutically intere- sting drug candidates, including 1,2,4-triazole nucleus. ${ }^{14-15}$ The action of these compounds is consisting on the inhibition of biosynthesis of ergosterol, the major steroid in fungal membrane by blocking $14-\alpha-$-methyl-steroids and breakdown of fungal membrane. So, in recent years, triazole-based chemosensories have been analyzed and have demonstrated to be successfully applicable in biological systems ${ }^{16,17}$ Beside these, vorozole, anastrozole and vetrozole having triazole moieties appear to be very effective aromatase inhibitors for preventing breast can- 
cer. ${ }^{18,19}$ In addition, the literature concerning heterocycles containing a triazole moiety is rich and papers published cover such subjects as vibrational characteristics, crystal structure determination, ab initio and DFT calculations on the tautomerism and protonation sides and molecular docking studies. ${ }^{20}$

To overcome cancer disease novel molecules are urgently needed, because the pharmacological fight against this disease has made significant progress in the last twenty years. Due to the biological importance, efforts are focused on 1,2,4,-triazole derivatives for the treatment of MCF-7 breast cancer. A series of 3-hydroxynaphthyl and $p$-tolyl substituted 1,2,4-triazoles (1-8) (Figure 1) were synthesized with high yields. Spectral investigations of naphthyl substituted 1,2,4-triazoles, have been recorded and confirmed by using density functional theory (DFT) carried out by (B3LYP/6-311G+(d,p)) basis set, FT-IR and NMR studies. In addition to the theoretical vibrational spectrum, density functional methods have also been used to calculate the molecular geometry, the atomic charges and some other molecular properties. The binding mode of these compounds to BRCA2 was also studied by molecular docking. In short a combination of computational methods and experimental approaches were used to discover a novel BRCA2 inhibitors and gain structural insight into their modes of binding.

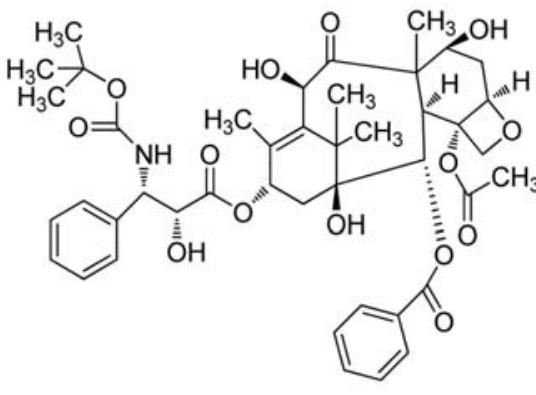

Docetaxel<smiles>CCC(=C(c1ccccc1)c1ccccc1)c1ccc(OCCN(C)C)cc1</smiles>

Tamoxifen<smiles>[R]n1c(-c2cc3ccccc3cc2O)n[nH]c1=S</smiles>

1-5<smiles>[R7]n1c(-c2ccc(C)cc2)n[nH]c1=S</smiles>

6-8

Figure 1. Chemical structures of standard drugs and tested compounds (1-8).

Table 1. Calculated B3LYP/ 6-311G $(\mathrm{d}, \mathrm{p})$ level vibrational frequencies $\left(\mathrm{cm}^{-1}\right)$ of compounds $((\mathbf{1 - 8}))$

\begin{tabular}{|c|c|c|c|c|c|c|c|c|}
\hline Assignment $\left(\mathrm{cm}^{-1}\right)$ & $\mathbf{1}$ & 2 & 3 & 4 & 5 & 6 & 7 & 8 \\
\hline$\overline{v(\mathrm{OH})_{(\text {naphthol })}}$ & 3831 & 3834 & 3831 & 3834 & 3667 & - & - & - \\
\hline $\mathbf{v}_{\text {sym }}(\mathbf{N H})_{(\text {triazole) }}$ & 3671 & 3668 & 3669 & 3668 & 3529 & 3660 & 3668 & 3668 \\
\hline $\mathrm{v}_{\mathrm{sym}}(\mathrm{CH})_{(\mathrm{Ar})}$ & 3219 & 3188 & 3191 & 3190 & 3190 & 3180 & 3197 & 3188 \\
\hline $\mathbf{v}_{\text {sym }}(\mathrm{CH})_{(\mathrm{Ar})}$ & 3191 & 3178 & 3178 & 3182 & - & 3161 & 3163 & 3165 \\
\hline $\mathbf{v}_{\text {asym }}(\mathrm{CH})_{(\mathrm{Ar})}$ & 3178 & 3150 & 3150 & 3166 & 3187 & 3103 & 3105 & 3104 \\
\hline $\mathbf{v}_{\text {sym }}(\mathrm{CH})_{(\text {alkene) }}$ & 3149 & - & - & - & - & - & - & - \\
\hline $\mathbf{v}_{\text {asym }}(\mathbf{C H})_{(\text {alkene) }}$ & 3132 & - & - & - & - & - & - & - \\
\hline $\mathbf{v}_{\text {sym }}\left(\mathrm{CH}_{2}\right)$ & 3076 & - & 3093 & - & - & - & 3078 & - \\
\hline$v_{\text {sym }}\left(\mathrm{CH}_{3}\right)$ & - & - & - & 3076 & - & 3079 & - & 3077 \\
\hline $\mathrm{v}_{\text {sym }}\left(\mathrm{CH}_{3}\right)$ & - & - & - & 3024 & & 3056 & - & 3022 \\
\hline $\mathbf{v}_{\text {sym }}(\mathbf{C H})_{\text {(adamantyl) }}$ & - & - & - & - & - & 3045 & - & - \\
\hline $\mathbf{v}_{\text {sym }}(C H)_{(\text {morpholine) }}$ & - & - & 2991 & - & - & - & 2998 & - \\
\hline $\mathbf{v}_{\text {sym }}(\mathrm{CH})_{\text {(morpholine) }}$ & - & - & 2964 & - & - & - & 2982 & - \\
\hline$v(C=C)_{(\text {ring })}$ & 1670 & 1670 & 1671 & 1670 & 1674 & 1655 & 1654 & 1653 \\
\hline $\mathbf{v}(\mathrm{C}=\mathrm{N})_{(\text {triazole })}$ & 1646 & 1646 & 1647 & 1651 & 1606 & 1593 & 1613 & 1639 \\
\hline tv $(C=C)$ & 1597 & 1600 & 1597 & 1599 & 1567 & 1539 & 1581 & 1580 \\
\hline $\mathbf{V}(\mathbf{N H})_{(\text {triazole) }}$ & 1545 & 1545 & 1544 & 1548 & 1540 & 1485 & 1541 & 1541 \\
\hline$\alpha v(\mathbf{C H})+v(\mathbf{C}=\mathrm{C})$ & 1481 & 1476 & 1484 & 1479 & 1486 & 1383 & 1495 & 1483 \\
\hline$\omega v\left(\mathrm{CH}_{2}\right)$ & 1427 & - & 1434 & - & - & 1372 & 1480 & - \\
\hline$\gamma \vee(\mathbf{C H})_{(\mathrm{Ar})}$ & 1406 & 1415 & 1407 & 1416 & 1425 & - & 1402 & 1439 \\
\hline$v(\mathrm{C}=\mathrm{N})_{(\text {triazole })}+\delta v(\mathrm{CH})$ & 1392 & 1402 & 1392 & 1402 & 1394 & 1313 & 1362 & 1416 \\
\hline $\mathrm{p} v(\mathrm{NH})+\mathrm{pv}(\mathrm{CH})$ & 1374 & 1390 & 1357 & 1390 & 1368 & 1303 & 1331 & 1392 \\
\hline $\mathrm{p} v(\mathrm{NH})+\mathrm{tv}\left(\mathrm{CH}_{2}\right)+\mathrm{pv}(\mathrm{CH})$ & 1349 & 1362 & 1325 & 1363 & 1328 & 1282 & 1294 & 1336 \\
\hline $\mathbf{v}(\mathrm{N}-\mathrm{N})_{(\text {triazole })}$ & 1186 & 1183 & 1185 & 1187 & 1196 & 1125 & 1178 & 1231 \\
\hline
\end{tabular}




\section{Results and Discussion}

\section{1. Infrared Spectroscopy}

The DFT/B3LYP method with $6-311 \mathrm{G}+(\mathrm{d}, \mathrm{p})$ basis set is used for calculating vibrational frequencies of 1,2,4triazole compounds, and Gauss-View molecular visualization program for the vibrational band assignments.

Table 1 illustrates simulated IR spectra both scaled and unscaled that show specific peaks for the molecule. All the calculated wave numbers are in good agreement with experimental values. There can be deficiency noted between the observed and the calculated values due to two factors; one is that theoretical calculations belong to the gaseous phase and the experimental results belong to the solid phase. Another one is the experimental values recorded in the presence of intermolecular interactions contrary to the calculations have been actually done on a single obtained molecule.

\section{2. Analysis of Frontier Molecular Orbitals}

Highest occupied molecular orbital (HOMO) and lowest unoccupied molecular orbital (LUMO) are the most important orbitals in a molecule and are called frontier molecular orbitals. These orbitals are very useful to characterize the chemical reactivity and kinetic stability of the molecule..$^{29,30}$

HOMO-1, HOMO, LUMO and LUMO+1orbitals are computed at the B3LYP with $6-311+\mathrm{G}(\mathrm{d}, \mathrm{p})$ level for compounds (1-8). The values of orbitals' energies are listed in Table 2. For the HOMO, electrons are mainly delocalized on the 1,2,4-triazole ring, beside this for the compounds 3 and 7 electrons are delocalized on the morpholine ring. For the LUMO the electrons are mainly delocalized on the naphthyl and tolyl ring for 1-4 and 5-8, respectively. Both of the highest occupied molecular orbital (HOMO) and lowest unoccupied molecular orbital (LUMO) are mainly delocalized on the rings, suggesting that the HOMO-LUMO are mostly $\pi^{*}$ antibonding type orbitals. Generally, it can be said that the electron flow is from HOMO to LUMO, in other words it is from the occupied HOMO of the 1,2,4-triazole to the LUMO of aromatic ring.

\section{3. Antitumor Activity Results}

The synthesized compounds (1-8) were screened for their antitumor activity against MCF-7 cell line. The $\mathrm{IC}_{50}$ values (concentration required to inhibit tumor cell proliferation by 50\%) for the synthesized compounds against MCF-7 cell were determined by using MTT test method. The $\mathrm{IC}_{50}$ values are summarized in Table 3 and the well-known anticancer drugs Tamoxifen and Docetaxel were used as positive controls. According to the results in Table 3, it was observed that compounds $\mathbf{1}$ and $\mathbf{2}$ illustrated medium to good anticancer activity against MCF-7 cell lines. Two of the most active compounds are 3 and 7 with $\mathrm{IC}_{50}$ values against the MCF-7 cell line 9.7 $\mu \mathrm{M}$ and $7.10 \mu \mathrm{M}$, respectively. Replacing the morpholine group with a naphthyl and adamanthyl group caused a slight loss of the $\mathrm{IC}_{50}$ values for compounds $\mathbf{6}(22.80 \mu \mathrm{M})$ and $\mathbf{8}(18.90 \mu \mathrm{M})$. The morpholine substituent on naphthyl and $p$-tolyl hydrazide groups had a major effect on the anticancer activity of the compounds $\mathbf{7}$ and $\mathbf{3}$ as compared to the compounds $\mathbf{1}(17.8 \mu \mathrm{M}), \mathbf{2}(25.10 \mu \mathrm{M})$ and $\mathbf{4}$ $(28.08 \mu \mathrm{M})$.

Table 3. Cytotoxicity of compounds (1-8), Docetaxel and Tamoxifen against MCF-7 cell lines

\begin{tabular}{cc}
\hline Compounds & $\mathbf{I C}_{\mathbf{5 0}}\left(\boldsymbol{\mu m _ { 0 } L ^ { - 1 }}\right)^{\mathbf{a}}$ for MCF-7 cell lines \\
\hline $\mathbf{1}$ & 17.8 \\
$\mathbf{2}$ & 25.10 \\
$\mathbf{3}$ & 9.7 \\
$\mathbf{4}$ & 28.08 \\
$\mathbf{5}$ & 27.10 \\
$\mathbf{6}$ & 22.80 \\
$\mathbf{7}$ & 7.10 \\
$\mathbf{8}$ & 18.90 \\
Docetaxel & 7.24 \\
Tamoxifen & 12.27 \\
\hline
\end{tabular}

\section{4. Docking Results}

The potent activity of the synthesized compounds (1-8) as new antitumor agents leads us to study the docking of these derivatives inside the active side of BRCA2

Table 2. Calculations of HOMO-LUMO energies for compounds ((1-8))

\begin{tabular}{ccccccc}
\hline Compounds & HOMO & LUMO & HOMO-1 & LUMO+1 & $\Delta \mathbf{E}_{\text {HOMO-LUMO }}$ & $\Delta \mathbf{E}\left(_{\text {HOMO+1)-(LUMO-1) }}\right.$ \\
\hline $\mathbf{1}$ & -0.20709 & -0.07176 & -0.21490 & -0.04048 & 0.13533 & 0.17442 \\
$\mathbf{2}$ & -0.20837 & -0.06989 & -0.21376 & -0.03915 & 0.13848 & 0.17774 \\
$\mathbf{3}$ & -0.20746 & -0.07031 & -0.21166 & -0.03910 & 0.13715 & 0.17256 \\
$\mathbf{4}$ & -0.20648 & -0.06872 & -0.21199 & -0.03731 & 0.13776 & 0.17468 \\
$\mathbf{5}$ & -0.21848 & -0.07420 & -0.22184 & -0.07268 & 0.14428 & 0.14916 \\
$\mathbf{6}$ & -0.21122 & -0.05535 & -0.21570 & -0.03780 & 0.15587 & 0.17790 \\
$\mathbf{7}$ & -0.20793 & -0.06696 & -0.21440 & -0.05250 & 0.14097 & 0.16190 \\
$\mathbf{8}$ & -0.25390 & -0.03823 & -0.29530 & -0.03443 & 0.16716 & 0.17510 \\
\hline
\end{tabular}


which is the potential target for antitumor agents. Figure S1 of the supplementary data illustrates the binding of the best generated conformers for compounds (1-8). Molecular docking parameters of the compounds (1-8) are shown in Table 4. The docking study finds out that the high affinity of synthesized compounds (1-8) within the binding pocket of BRCA2 increases the determined activities of the 1,2,4-triazole derivatives as a potential antitumor agent. Especially, active compound 7, when modeled in the active side of BRCA2 revealed strong binding activities (Figure 2).

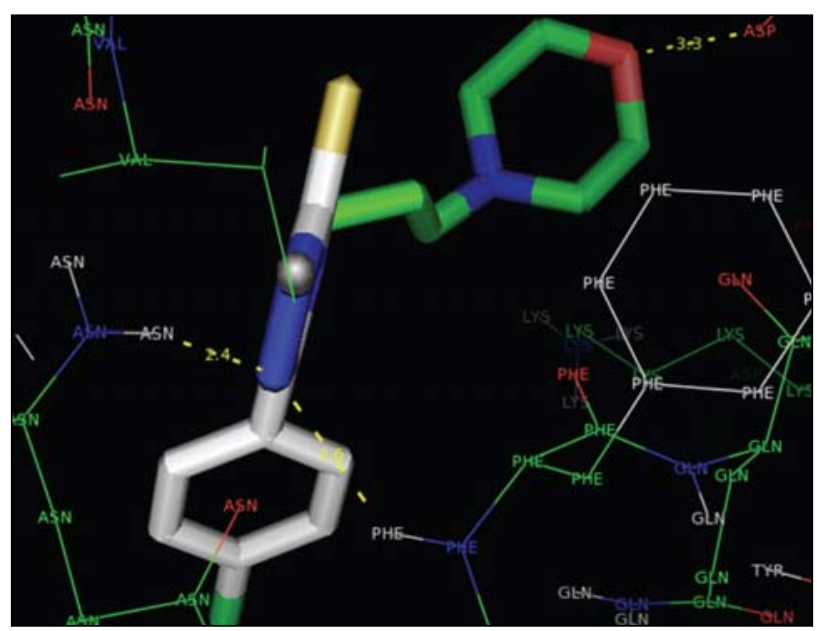

Figure. 2 Computed binding geometry of compound $\mathbf{7}$ in the active site of BRCA2<smiles>C=CCn1c(-c2cc3ccccc3cc2O)n[nH]c1=S</smiles><smiles>C=CCn1c(S)nnc1-c1cc2ccccc2cc1O</smiles>

1 (Tautomer-A)

1 (Tautomer-B)<smiles>C=CCn1c(-c2cc3ccccc3cc2[O-])n[nH]c1=S</smiles>

1 (Deprotonated-B)<smiles>C=CCn1c(-c2cc3ccccc3cc2[O-])n[n-]c1=S</smiles>

1 (Deprotonated-C)<smiles>C=CCN1C(S)=NNC1=C1C=c2ccccc2=CC1=O</smiles>

1 (Tautomer-C)<smiles></smiles>

1 (Conformer-A)<smiles>C=CCn1c(-c2cc3ccccc3cc2O)n[nH]c1=S</smiles>

1 (Deprotonated-A)<smiles>C=CCN1C(=S)NNC1=C1C=c2ccccc2=CC1O</smiles>

1 (Isomer-C)

Figure 3. Neutral, deprotonated and tautomeric structures of $\mathbf{1}$. 
Table 4. Docking results of the compounds (1-8), Docetaxel and Tamoxifen

\begin{tabular}{cccc}
\hline Compounds & Docking Results & $\begin{array}{c}\text { Bond distance } \\
(\mathbf{\AA})\end{array}$ & $\begin{array}{c}\text { Binding Energy } \\
(\mathbf{k c a l} / \mathbf{m o l})\end{array}$ \\
\hline $\mathbf{1}$ & Ser and Glu & 2.2 & -6.6 \\
$\mathbf{2}$ & Arg & 2.6 & -6.7 \\
$\mathbf{3}$ & Tyr & 2.2 & -5.6 \\
$\mathbf{4}$ & Ser & 2.8 & -7.6 \\
$\mathbf{5}$ & Lys & 2.3 & -7.1 \\
$\mathbf{6}$ & Tyr & 2.1 & -5.5 \\
$\mathbf{7}$ & Asn, Asp and Phe & $2.4 ; 3.3$ and 2.6 & -5.0 \\
$\mathbf{8}$ & Glu & 2.7 & -6.2 \\
Docetaxel & Glu and Asp & $3.2 ; 2.6 ; 2.1 ; 1.7$ & \\
& & and & \\
Tamoxifen & & $3.5 ; 2.0$ & -5.0 \\
& Tyr and Lys & 2.8 and 2.9 & -7.0 \\
\hline
\end{tabular}

Microspecies distribution (\%)

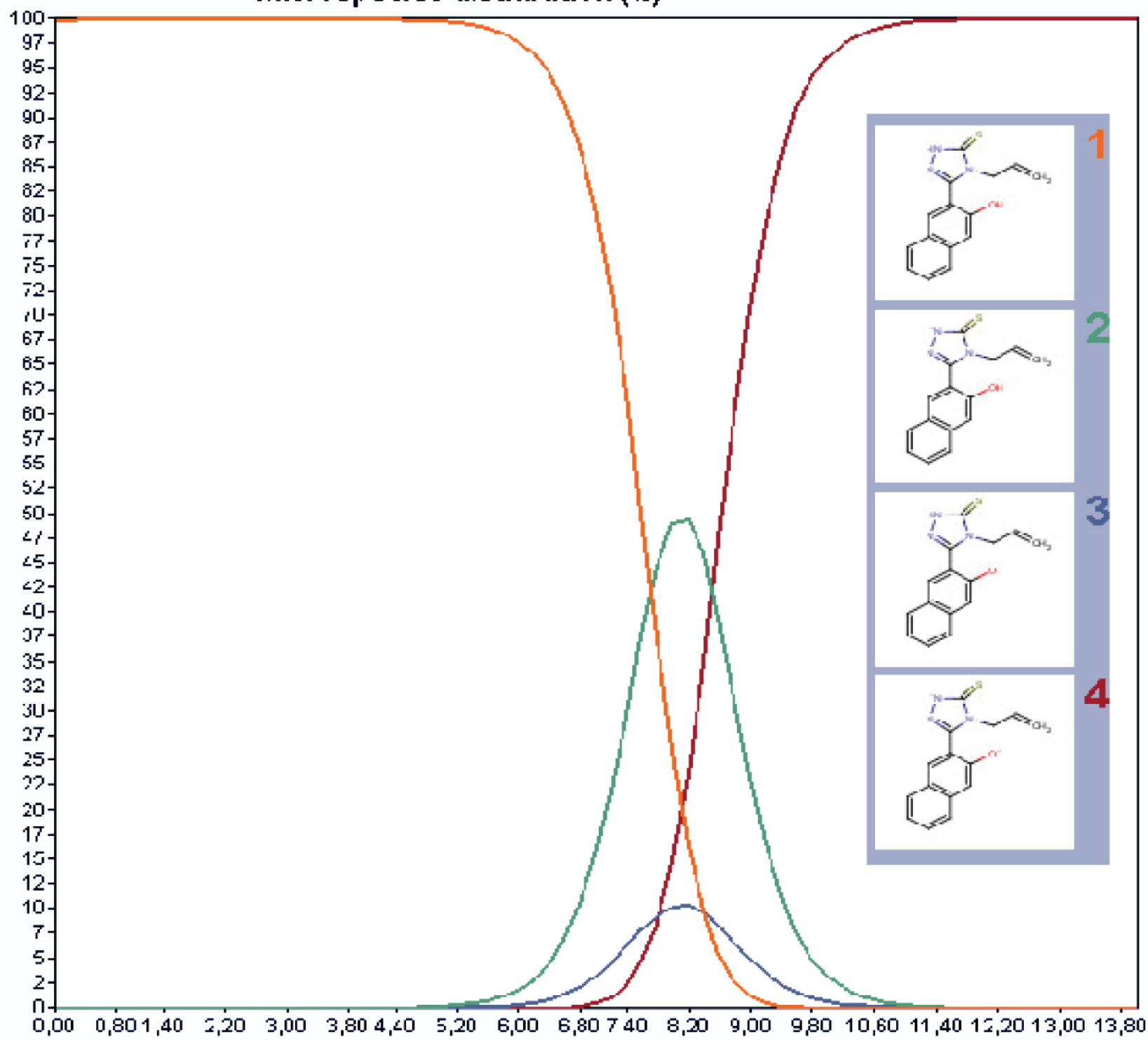

Figure 4. Species repartition of compound $\mathbf{1}$ in solution at different $\mathrm{pH}$. 
At 6.8-9.8 $\mathrm{pH}$ windows, the coexistence of four different species of compound $\mathbf{1}$ and certainly for the rest of series $\mathbf{2 - 5}$ can be easily justified (Figure 4).

Current thinking in the generation of specific drug leads embodies the concept of achieving high molecular diversity within the boundaries of reasonable drug-like properties. ${ }^{31}$ Natural and semi-natural products, for examples Streptomycin, Penicillin, Imipenem, Docetaxel and Tamoxifen have high chemical diversity, biochemical specificity and other molecular properties that make them favorable as lead and standard references (SR) structures for drug discovery, and which serve to differentiate them from libraries of synthetic and combinatorial compounds. Various investigators have used computational methods to understand differences between natural products and other sources of drug leads. ${ }^{32}$

Modern drug discovery is based in large part on high throughput screening of small molecules against macromolecular disease targets requiring that molecular screening libraries contain drug-like or lead-like compounds. We have analyzed known standard references (SR) for drug-like and lead-like properties. With this information in hand, we have established a strategy to design specific drug-like or lead-like 1-8.

\section{5. 1. Petra Analysis}

On the basis of the new finding, we can conclude that the compounds (1-8) having thiocarbonyl $\mathrm{C}=\mathrm{S}$ and $\mathrm{NH}$ of thiocarbamide moiety possess a potential antibacterial $(\mathrm{OH}-\mathrm{N})$ or $(\mathrm{OH}-\mathrm{N})$ and antikinase $(\mathrm{NH}-\mathrm{C}=\mathrm{S})$ pharmacophore sites (Figure 5). For antibacterial activity, the compound posses $\left(\mathrm{X}^{\delta-}-\mathrm{Y}^{\delta+}\right)$ pharmacophore site and also it was hypothesised that the difference in charge between
$\mathrm{X}$ and $\mathrm{Y}$ of the same dipolar pharmacophoric site should facilitate the inhibition of bacteria more than viruses. In contrast to antibacterial agent, the antiviral drug should have $\left(\mathrm{X}^{\delta_{-}}-\mathrm{Y}^{\delta_{-}}\right)$pharmacophore site with respect of some architectural parameters (dihedral angle $=0-10$ degree and distance $\mathrm{d}_{x-y}=3-3.5 \AA$ ). ${ }^{33-39}$ This can be applied for all compounds described here (Figure 5).

\section{Molinspiration Calculations}

$\operatorname{cLog} P$ (octanol/water partition coefficient) is calculated by the methodology developed by Molinspiration as a sum of fragment-based contributions and correction factors (Table 5). The method is very robust and is able to process practically all organic and most organometallic molecules. Molecular Polar Surface Area PSA is calculated as a sum of fragment contributions. ${ }^{33-39} \mathrm{O}-, \mathrm{N}-$ and $\mathrm{S}-$ centered polar fragments are considered. PSA has been shown to be a very good descriptor characterizing drug absorption, including intestinal absorption, bioavailability, Caco-2 permeability and blood-brain barrier penetration. Prediction results of compounds (1-8) molecular properties (TPSA, GPCR ligand and MIC are valued (Table 5). Lipophilicity (cLog $P$ value) and polar surface area (TPSA) values are two important properties for the prediction of oral bioavailability of drug molecules. ${ }^{33-39}$ Therefore c$\log P$ and TPSA values for compounds (1-8) were calculated using Molinspiration software programs and compared with the values obtained for standard drugs Docetaxel and Tamoxifen. For majority of the compounds, with some exceptions (5 and $\mathbf{6})$, the calculated $\operatorname{cLog} P$ values were around 2.15-4.65 $(<5)$, which is the upper limit for the drugs to be able to penetrate through bio-membranes according to Lipinski's rule. So these compounds are expected to present good bioavailability.

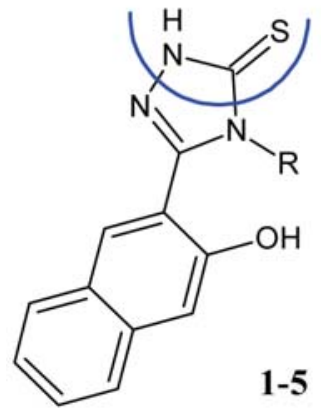

(Tautomer-01)

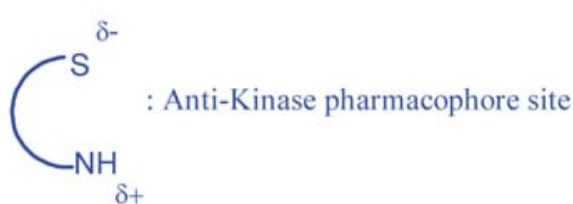

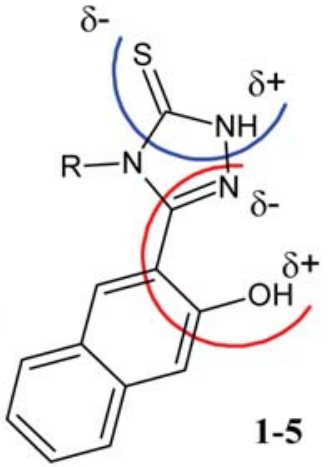

(Tautomer-02)

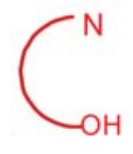

Figure 5. Identification of pharmacophore sites of series 1-5 
Table 5. Molinspiration calculations of compounds (1-8)

\begin{tabular}{cccccccccccc}
\hline \multirow{2}{*}{ Compounds } & \multicolumn{4}{c}{ Molecular Properties ${ }^{\mathrm{a}}$} & \multicolumn{4}{c}{} & \multicolumn{3}{c}{ Bioactivity Scores $^{\mathrm{b}}$} \\
& $\mathbf{c L o g}$ & TPSA & OHNH & VIOL & VOL & GPCR & ICM & KI & NRL & PI & EI \\
\hline $\mathbf{1}$ & 3.09 & 54 & 2 & 0 & 246 & -0.71 & -0.79 & -0.93 & -0.75 & -0.90 & -0.48 \\
$\mathbf{2}$ & 3.73 & 54 & 2 & 0 & 273 & -0.39 & -0.53 & -0.52 & -0.59 & -0.64 & -0.39 \\
$\mathbf{3}$ & 2.60 & 66 & 2 & 0 & 330 & -0.28 & -0.60 & -0.37 & -0.47 & -0.42 & -0.28 \\
$\mathbf{4}$ & 4.17 & 54 & 2 & 0 & 289 & -0.41 & -0.59 & -0.55 & -0.59 & -0.66 & -0.44 \\
$\mathbf{5}$ & 5.09 & 54 & 2 & 1 & 316 & -0.33 & -0.46 & -0.44 & -0.47 & -0.60 & -0.30 \\
$\mathbf{6}$ & 5.20 & 34 & 1 & 1 & 318 & -0.39 & -0.75 & -0.64 & -0.59 & -0.51 & -0.35 \\
$\mathbf{7}$ & 2.15 & 46 & 1 & 0 & 295 & -0.47 & -0.82 & -0.63 & -0.75 & -0.64 & -0.52 \\
$\mathbf{8}$ & 4.65 & 34 & 1 & 0 & 281 & -0.47 & -0.62 & -0.66 & -0.70 & -0.80 & -0.51 \\
Docetaxel & 4.24 & 224 & 5 & 2 & 724 & -1.74 & -2.81 & -2.89 & -2.38 & -1.10 & -2.05 \\
Tamoxifen & 6.06 & 12 & 0 & 1 & 376 & 0.30 & 0.01 & -0.01 & 0.57 & 0.04 & 0.32 \\
\hline
\end{tabular}

a) TPSA: Total of Polar surface area; $\mathrm{OHNH}$ : $\mathrm{OH}-\mathrm{N}$ or O-HN Interraction; VIOL: Violation of Lipinski rules; VOL: Volume. b) GPCR: GPCR ligand; ICM: Ion channel modulator; KI: Kinase inhibitor; NRL: Nuclear receptor ligamd; PI: Protease inhibitor; EI: Enzyme inhibitor

The lowest degree of lipophilicity among all the compounds was exhibited by compounds (1-8), which are an indication for good water solubility. The polar surface area (TP$\mathrm{SA}$ ) is calculated from the surface areas that are occupied by oxygen and nitrogen atoms and by hydrogen atoms attached to them. Thus, the TPSA is closely related to the hydrogen bonding potential of a compound ${ }^{33-39}$ Molecules with TPSA values around 160 or more are expected to exhibit poor intestinal absorption. Table 5 shows that all the compounds are within this limit. It is to be noted that $\operatorname{cog} P$ and TPSA values are the two important parameters, although not sufficient criteria for predicting oral absorption of a drug. An interesting thing of this study is that all the compounds (except $\mathbf{5 , 6}$ ) obey the Rule of 5 and have zero violation of the Rule of 5 . Two or more violations of the Rule of 5 suggest the probability of problems in bioavailability of the standard drug. ${ }^{33-39}$ Properties like hydrophobicity, electronic distribution, hydrogen bonding characteristics, molecule size, flexibility and presence of various pharmacophores features influence the behavior of molecule in a living organism, including bioavailability, transport properties, affinity to proteins, reactivity, toxicity, metabolic stability and many others. Activity of the synthesized compounds with two standard drugs were rigorously analyzed under four criteria of known successful drug activity in the areas of GPCR ligand activity, ion channel modulation, kinase inhibition activity, and nuclear receptor ligand activity. Results are shown in Table 5 by means of numerical assignment. Likewise all compounds have a consistent negative values in all categories and numerical values conforming and comparable to standard drugs used for comparison. Therefore, these compounds are expected to have near similar activity to the standard drugs used based upon these four rigorous criteria (GPCR ligand, ion channel modulator, kinase inhibitor and nuclear receptor ligand).

\section{5. 2. Osiris Calculations}

Remarkably well behaved mutagenicity of diverse synthetic molecules classified in the database of Celeron
Company of Switzerland can be used to quantify the role played by various organic groups in promoting or interfering with the way a drug can associate with DNA. The Osiris calculations are presented in Table 6. Toxicity risks (mutagenicity, tumorogenicity, irritation, reproduction) and physicochemical properties (cLog $P$, solubility, druglikeness and drug-score) of compounds (1-8) were calculated by the methodology developed by Osiris. The toxicity risk predictor locates fragments within a molecule, which indicate a potential toxicity risk. Toxicity risk alerts are an indication that the drawn structure may be harmful concerning the risk categories specified. From the data evaluated in Table 6 it is prudent to note that here majority of structures (8/8) are supposed to be mutagenic, with reproductive effects when run through the mutagenicity assessment system in comparison with the standard drug. Low hydrophilicities and therefore high $\operatorname{cLog} P$ values may cause poor absorption or permeation. It has been shown that for compounds to have a reasonable probability of good absorption, their $\operatorname{cLog} P$ value must not be greater than 5.0. On this basis, all the compounds (1-8) possessed $\operatorname{cLog} P$ values in the acceptable range. On this basis (Table 6), all the compounds 1-8 possessed $\operatorname{cLog} P$ values in the acceptable range $(2.1<\operatorname{cog} P<4.67)$. Here compound 5 is subject of exception (cLog $P=5.18)$.

The aqueous solubility of a compound significantly affects its absorption and distribution characteristics. Typically, a low solubility goes along with a bad absorption and therefore the general aim is to avoid poorly soluble compounds. Our estimated solubility ( $\mathrm{S}$ ) value is a unit stripped logarithm (base 10) of a compound's solubility in $\mathrm{mol} / \mathrm{L}$. There are more than $80 \%$ of the drugs on the market having an (estimated) $\mathrm{S}$ value greater than -4 . In case of compounds (1-8), values of solubility (S) are in -2 to -6 range. Further, Table 6 shows drug likeness of compounds (1-8) which is not in the comparable zone with that of standard drugs used for comparison. The majority of reported compounds (1-8) showed no toxicity risk but have low drug score as compared with the standard drugs used here. 
Table 6: Osiris calculations of compounds (1-8)

\begin{tabular}{|c|c|c|c|c|c|c|c|c|c|}
\hline \multirow[t]{2}{*}{ Compounds } & \multicolumn{4}{|c|}{ Toxicity Risks $^{\mathrm{a}}$} & \multicolumn{5}{|c|}{ Bioavailability and Drug-Score ${ }^{\mathrm{b}}$} \\
\hline & MUT & TUM & IRRIT & RE & MW & CLP & $\mathbf{S}$ & DL & D-S \\
\hline 1 & 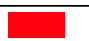 & 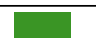 & 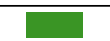 & 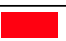 & 283 & 3.16 & -4.31 & -5.21 & 0.14 \\
\hline 2 & & & & & 319 & 3.98 & -5.65 & -3.07 & 0.10 \\
\hline 3 & & [ & $\mathbf{L}$ & & 370 & 2.61 & -3.56 & -2.12 & 0.16 \\
\hline 4 & & & a & & 333 & 4.32 & -5.99 & -4.77 & 0.09 \\
\hline 5 & & & & & 369 & 5.18 & -7.26 & -3.81 & 0.04 \\
\hline 6 & & & & & 339 & 4.40 & -5.44 & 0.10 & 0.15 \\
\hline 7 & & & & & 318 & 2.10 & -2.60 & 2.14 & 0.30 \\
\hline 8 & & & & & 317 & 4.67 & -6.29 & 0.46 & 0.08 \\
\hline Docetaxel $^{\mathrm{c}}$ & & & & & 807 & 2.61 & -5.81 & -60.4 & 0.16 \\
\hline Tamoxifen $^{c}$ & $\mathbf{z}$ & $\mathbf{D}$ & 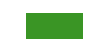 & 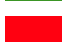 & 371 & 4.72 & -4.4 & 6.3 & 0.35 \\
\hline
\end{tabular}

not toxic, $\square$ slightly toxic,

highly toxic, a) MUT: mutagenic; TUM: tumorigenic; IRRIT: irritant; RE: reproductive effective.

b) CLP: cLogP, S: Solubility, DL: druglikness, DS: Drug-Score. c) Standard drug

So the preliminary structure-activity relationship (SAR) analysis suggested that the introduction of appropriate substitutent (4-(tetrahydro- $2 \mathrm{H}$-pyran-4-yl)butyl) instead of aryl rings (R or R") will enhance antitumoural activity of these compounds. The alkylation of the nitrogen atom of the 4-substituent-5-thioxo-4,5-dihydro- $1 \mathrm{H}-1,2,4-$ triazole-3-yl group will keep antiviral pharmacophore site ready for possible bioactivity. POM analyses confirm the existence of an antitumoral pharmacophore site $(\mathrm{NH}-$ $\mathrm{C}=\mathrm{S})$.

In summary, a series of 3-hydroxynaphthyl and $p$ tolyl substituted 1,2,4,-triazoles were successfully synthesized and characterized by combination of elemental analyses, ${ }^{1} \mathrm{H}$ and ${ }^{13} \mathrm{C}$-NMR spectra, IR and theoretical methods. The calculated geometrical parameters were found to be in good agreement with the theoretical data. In vitro antitumor activity assay showed that, the morpholine substituent of side chain greatly influences the antitumor activity of the 1,2,4,-triazoles against MCF-7 human breast cancer line. Results revealed that compounds 3 and 7 showed broad spectrum anticancer activity with $\mathrm{IC}_{50}$ values $9.7 \mu \mathrm{M}$ and $7.10 \mu \mathrm{M}$, respectively and their activity is comparable to that of the standard drugs. So; the present work established structure-activity and structure-cytotoxicity information for the 3-hydroxynaphthyl and $p$-tolyl substituted 1,2,4-triazoles as anti-breast cancer agents. Breast cancer inhibition through 1,2,4,-triazoles and its derivatives was elucidated by means of density functional theory (DFT)-derived reactivity indexes. The DFT calculated parameters and experimental cancer inhibition efficiency $\left(\mathrm{IC}_{50}\right)$ indicate that their inhibition effect is closely related to the frontier orbital energies, polarizability, electronic chemical potential and global nucleophilicity. Beside these; these observations were exponible by computational docking simulation. Docking studies illustrated that compound 7 has high binding affinity with the BRCA2 because of the presence of conserved binding side amino acid residues Asp, Phe and Asn thus demonstrating its high stability along with activity potential similar to one of the control as Tamoxifen.

\section{Experimental}

\section{1. Chemistry}

All the reagents and solvents were of analytical grade. The human breast carcinoma MCF-7 cell lines were obtained from the American Type Culture Collection (ATCC). Dulbecco's modified Eagle's medium (DMEM) and new-born calf serum were purchased from Hyclone (Waltham, MA, USA); and trypsin, penicillin, streptomycin. Infrared (IR) spectrum was determined on a PerkinElmer Spectrum One Fourier transform-infrared (FT-IR) spectrometer. NMR spectra were recorded on Bruker $300-\mathrm{MHz}$ spectrometer. Elemental analyses were performed on a LECO model 932 instrument. The cells were incubated under $5 \% \mathrm{CO}_{2} /$ air at $37{ }^{\circ} \mathrm{C}$ conditions at Nuaire humidified carbon dioxide incubator (Playmouth, $\mathrm{MN}$, USA). Cells' state was controlled by inverted microscope (Soif Optical Inc. China) and results are expressed as Mean \pm STD. Statistical analysis and comparison between mean values for cytotoxicity were performed by Tukey variance analysis (SPSS 10.0 for Windows; Chicago, IL, USA).

\section{2. General Procedure for Compounds (1-8)}

3-hydroxy-2-naphthohydrazide (or $p$-toly hydrazide) $(0.01 \mathrm{~mol})$ and different isothiocyanate $(0.01 \mathrm{~mol})$ were dissolved in $30 \mathrm{~mL}$ THF. The reaction mixture was stirred and refluxed at $80{ }^{\circ} \mathrm{C}$ for $4 \mathrm{~h}$. The resulting precipitate was collected by filtration, washed with cold THF. The compound (B) was added to a solution of $\mathrm{NaOH}(10 \mathrm{~mL}$, $4 \mathrm{~N}$ ) and the reaction mixture was maintained under reflux for $5 \mathrm{~h}$. Then the reaction mixture was acidified with $\mathrm{HCl}(37 \%)$ and the pure product was obtained by recrystallization in ethanol (Scheme 1). 
<smiles>NNC(=O)c1cc2ccccc2cc1O</smiles>

A<smiles>Cc1ccc(C(=O)NN)cc1</smiles><smiles>[R]=CCC</smiles><smiles></smiles>

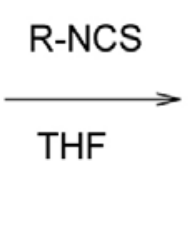

R"-NCS

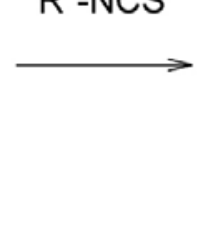<smiles>[R]NC(=S)NNC(=O)c1cc2ccccc2cc1O</smiles>

B

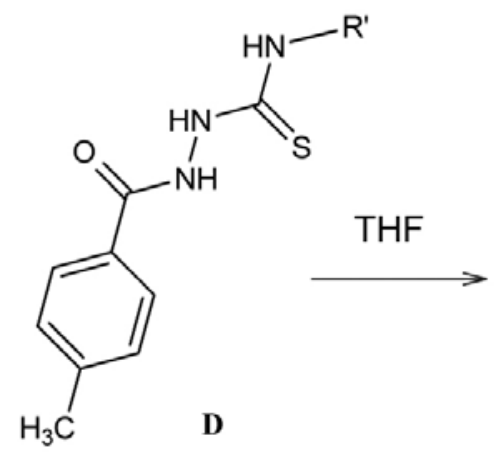

$3: R=\overbrace{O}^{N}$<smiles></smiles>

$8: R^{\prime \prime}=$

Scheme 1. Synthesis of 1,2,4-triazole compounds (1-8).

5-(3-hydroxynaphthalen-2-yl)-4-(prop-2-en-1-yl)-2,4dihydro-3H-1,2,4-triazole-3-thione (1)

The compound has been synthesized according to the literature. ${ }^{20}$

\section{5-(3-hydroxynaphthalen-2-yl)-4-phenyl-2,4-dihydro-} 3H-1,2,4-triazole-3-thione (2)

The compound has been synthesized according to the literature. $^{22,23}$

5-(3-hydroxynaphthalen-2-yl)-4-[3-(morpholin-4yl)propyl]-2,4-dihydro-3H-1,2,4-triazole-3-thione (3) White crystals in THF: Yield: $285 \mathrm{mg},(88 \%)$. Analysis:
Found: C 61.57, H 6.03, N 15.06, S 8.68\%. Calculated for $\mathrm{C}_{19} \mathrm{H}_{22} \mathrm{~N}_{4} \mathrm{OS}: \mathrm{C} 61.60, \mathrm{H} 5.99, \mathrm{~N} 15.12$, S: 8.66\%. IR data $\left(\mathrm{KBr}\right.$ pellet, $\left.\mathrm{cm}^{-1}\right): 3330 v(\mathrm{~N}-\mathrm{H}), 3290 v(\mathrm{O}-\mathrm{H}), 3199-$ $3150 v(\mathrm{Ar}-\mathrm{CH}), 2925-2899 v(\mathrm{C}-\mathrm{H}), 1690 \vee(\mathrm{C}=\mathrm{C}), 1648$ $v(\mathrm{C}=\mathrm{N}), 1514 v(\mathrm{~N}-\mathrm{H}), 1062 v(\mathrm{~N}-\mathrm{N}),{ }^{1} \mathrm{H}-\mathrm{NMR}(400$ MHz, DMSO- $\left.d_{6}\right): 13.97$ (s,1H, N-H), 10.73 (s, 1H, OH), 8.04 (s, $1 \mathrm{H}, \mathrm{Ar}-\mathrm{H}), 7.89\left(\mathrm{~d}, 1 \mathrm{H}, \mathrm{Ar}-\mathrm{H},{ }^{3} J\left({ }^{1} \mathrm{H}-{ }^{1} \mathrm{H}\right)=8 \mathrm{~Hz}\right)$, $7.81\left(\mathrm{~d}, 1 \mathrm{H}, \mathrm{Ar}-\mathrm{H},{ }^{3} J\left({ }^{1} \mathrm{H}-{ }^{1} \mathrm{H}\right)=8 \mathrm{~Hz}\right), 7.51(\mathrm{t}, 1 \mathrm{H}, \mathrm{Ar}-\mathrm{H}$, $\left.{ }^{3} J\left({ }^{1} \mathrm{H}^{-}{ }^{1} \mathrm{H}\right)=8 \mathrm{~Hz}\right), 7.39-7.35(\mathrm{~m}, 2 \mathrm{H}, \mathrm{Ar}-\mathrm{H}), 3.95(\mathrm{t}, 2 \mathrm{H}$, $\left.\mathrm{CH}_{2},{ }^{3} \mathrm{~J}\left({ }^{1} \mathrm{H}-{ }^{1} \mathrm{H}\right)=4 \mathrm{~Hz}\right), 3.18\left(\mathrm{~m}, 8 \mathrm{H}, \mathrm{C}_{\text {Morpholin }} \mathrm{H}_{2}\right)$, 2.11(s, $\left.2 \mathrm{H}, \mathrm{CH}_{2}\right), 1.98\left(\mathrm{~s}, 2 \mathrm{H}, \mathrm{CH}_{2}\right), 1.68\left(\mathrm{~s}, 2 \mathrm{H}, \mathrm{CH}_{2}\right)$, ${ }^{13} \mathrm{C}-\mathrm{NMR}\left(75 \mathrm{MHz}, \mathrm{DMSO}-d_{6}\right): 166,153,150,135,132$, 129, 128, 127, 126, 124, 116, 110, 66, 54, 53, 42, 24. 
5-(3-hydroxynaphthalen-2-yl)-4-(4-methylphenyl)-2,4dihydro-3H-1,2,4-triazole-3-thione (4)

The compound have been synthesized according to the literature. ${ }^{23}$

5-(3-hydroxynaphthalen-2-yl)-4-(naphthalen-1-yl)2,4-dihydro-3H-1,2,4-triazole-3-thione (5)

White crystals in THF: Yield: $0.439 \mathrm{~g}$, (79\%). Analysis: Found: C 71.52, H 5.09, N 11.37, S 8.68\%. Calculated for $\mathrm{C}_{22} \mathrm{H}_{15} \mathrm{~N}_{3} \mathrm{OS}$ : C 71.49, H 5.03, N 11.30, S 8.62\%. IR data $\left(\mathrm{KBr}\right.$ pellet, $\left.\mathrm{cm}^{-1}\right): 3307 \mathrm{v}(\mathrm{N}-\mathrm{H}), 3250 \mathrm{v}(\mathrm{O}-\mathrm{H}), 3180-$ $3160 v(\mathrm{Ar}-\mathrm{CH}), 2980 v(\mathrm{C}-\mathrm{H}), 1671 v(\mathrm{C}=\mathrm{C}), 1620$ $v(\mathrm{C}=\mathrm{N}), 1540 v(\mathrm{~N}-\mathrm{H}), 1093 v(\mathrm{~N}-\mathrm{N}),{ }^{1} \mathrm{H}-\mathrm{NMR}(400$ $\left.\mathrm{MHz}, \mathrm{DMSO}-d_{6}\right): \delta 14.40(\mathrm{~s}, 1 \mathrm{H}, \mathrm{N}-\mathrm{H}), 10.38(\mathrm{~s}, 1 \mathrm{H}$, $\mathrm{OH}), 7.98(\mathrm{~s}, 1 \mathrm{H}, \mathrm{Ar}-\mathrm{H}), 7.93\left(\mathrm{t}, 2 \mathrm{H}, \mathrm{Ar}-\mathrm{H},{ }^{3} \mathrm{~J}\left({ }^{1} \mathrm{H}-{ }^{1} \mathrm{H}\right)=8\right.$ $\mathrm{Hz}), 7.68\left(\mathrm{~d}, 1 \mathrm{H}, \mathrm{Ar}-\mathrm{H},{ }^{3} \mathrm{~J}\left({ }^{1} \mathrm{H}-{ }^{-1} \mathrm{H}\right)=8 \mathrm{~Hz}\right), 7.59-7.48(\mathrm{~m}$, $5 \mathrm{H}, \mathrm{Ar}-\mathrm{H}), 7.37\left(\mathrm{t}, 1 \mathrm{H}, \mathrm{Ar}-\mathrm{H},{ }^{3} \mathrm{~J}\left({ }^{1} \mathrm{H}-{ }^{1} \mathrm{H}\right)=8 \mathrm{~Hz}\right), 7.22(\mathrm{t}$, $\left.2 \mathrm{H}, \operatorname{Ar}-\mathrm{H},{ }^{3} \mathrm{~J}\left({ }^{1} \mathrm{H}-{ }^{1} \mathrm{H}\right)=8 \mathrm{~Hz}\right), 7.05(\mathrm{~s}, 1 \mathrm{H}, \mathrm{Ar}-\mathrm{H})$, ${ }^{13} \mathrm{C}-\mathrm{NMR}\left(75 \mathrm{MHz}, \mathrm{DMSO}-d_{6}\right)$ : $169,153,150,135,134$, $132,131,130,129,128.8,128.4,128.0,127,126.8$, $126.2,125,124,123,116,109$.

\section{5-(p-toly)-4-(tricyclo[4.3.1.1 $\left.{ }^{3,8}\right]$ undec-1-yl)-2,4-dihy-} dro-3H-1,2,4-triazole-3-thione (6)

The compound have been synthesized according to the literature. ${ }^{20}$

5-(p-toly)-4-[3-(morpholin-4-yl)propyl]-2,4-dihydro3H-1,2,4-triazole-3-thione (7)

White crystals in THF. Yield: $0.495 \mathrm{~g}$, (88\%). Analysis: Found: C 60.34, H 6.92, N 17.55, S 10.12\%. Calculated for $\mathrm{C}_{16} \mathrm{H}_{22} \mathrm{~N}_{4} \mathrm{OS}$ : C 60.35, H 6.96, N 17.59, S 10.07\%. IR data $\left(\mathrm{KBr}\right.$ pellet, $\left.\mathrm{cm}^{-1}\right): 3345 \mathrm{v}(\mathrm{N}-\mathrm{H}), 3090-3000$ $v(\mathrm{Ar}-\mathrm{CH}), 2867 v(\mathrm{C}-\mathrm{H}), 1680 v(\mathrm{C}=\mathrm{C}), 1625 v(\mathrm{C}=\mathrm{N})$, $1510 v(\mathrm{~N}-\mathrm{H}), 1025 \mathrm{v}(\mathrm{N}-\mathrm{N}),{ }^{1} \mathrm{H}-\mathrm{NMR}(400 \mathrm{MHz}$, DMSO- $\left.d_{6}\right) ; \delta 14.14(\mathrm{~s}, 1 \mathrm{H}, \mathrm{N}-\mathrm{H}), 8.04(\mathrm{~s}, 1 \mathrm{H}, \mathrm{Ar}-\mathrm{H}), 7.12$ $\left(\mathrm{d}, 2 \mathrm{H}, \mathrm{Ar}-\mathrm{H},{ }^{3} J\left({ }^{1} \mathrm{H}-{ }^{1} \mathrm{H}\right)=12 \mathrm{~Hz}\right), 7.01(\mathrm{~d}, 2 \mathrm{H}, \operatorname{Ar}-\mathrm{H}$, $\left.{ }^{3} J\left({ }^{1} \mathrm{H}-{ }^{-1} \mathrm{H}\right)=12 \mathrm{~Hz}\right), 3.91\left(\mathrm{t}, 2 \mathrm{H}, \mathrm{CH}_{2},{ }^{3} J\left({ }^{1} \mathrm{H}^{-1} \mathrm{H}\right)=4 \mathrm{~Hz}\right)$, $3.12\left(\mathrm{~m}, 8 \mathrm{H}, \mathrm{C}_{\text {Morpholin }}-\mathrm{H}_{2}\right), 2.08\left(\mathrm{~s}, 2 \mathrm{H}, \mathrm{CH}_{2}\right), 1.99(\mathrm{~s}, 2 \mathrm{H}$, $\left.\mathrm{CH}_{2}\right), 1.69\left(\mathrm{~s}, 2 \mathrm{H}, \mathrm{CH}_{2}\right),{ }^{13} \mathrm{C}-\mathrm{NMR}\left(75 \mathrm{MHz}, \mathrm{DMSO}-d_{6}\right)$ : 166, 152, 141, 131, 129, 127, 65, 55, 53, 41, 24.

\section{5-(4-methylphenyl)-4-(naphthalen-1-yl)-2,4-dihydro-} 3H-1,2,4-triazole-3-thione (8)

Yellow crystals in THF: Yields: $610 \mathrm{mg}$, (90\%). Analysis: Found: C 71.89, H 4.75, N 13.20, S 10.12\%. Calculated for $\mathrm{C}_{19} \mathrm{H}_{15} \mathrm{~N}_{3} \mathrm{~S}$ : C 71.90, $\mathrm{H} 4.76, \mathrm{~N} 13.24, \mathrm{~S} 10.10 \%$. IR data $\left(\mathrm{KBr}\right.$ pellet, $\left.\mathrm{cm}^{-1}\right): 3510 \mathrm{v}(\mathrm{N}-\mathrm{H}), 3195 \mathrm{v}(\mathrm{Ar}-\mathrm{CH})$, 2891-2840 v(C-H), $1671 \vee(\mathrm{C}=\mathrm{C}), 1620 v(\mathrm{C}=\mathrm{N}), 1545$ $v(\mathrm{~N}-\mathrm{H}), 1087 \mathrm{v}(\mathrm{N}-\mathrm{N}),{ }^{1} \mathrm{H}-\mathrm{NMR}\left(400 \mathrm{MHz}, \mathrm{DMSO}-d_{6}\right)$ : $\delta 14.28(\mathrm{~s}, 1 \mathrm{H}, \mathrm{N}-\mathrm{H}), 8.13\left(\mathrm{~d}, 1 \mathrm{H}, \mathrm{Ar}-\mathrm{H},{ }^{3} \mathrm{~J}\left({ }^{1} \mathrm{H}-{ }^{1} \mathrm{H}\right)=8\right.$ $\mathrm{Hz}), 8.07\left(\mathrm{~d}, 2 \mathrm{H}, \mathrm{Ar}-\mathrm{H},{ }^{3} \mathrm{~J}\left({ }^{1} \mathrm{H}-{ }^{1} \mathrm{H}\right)=8 \mathrm{~Hz}\right), 7.68-7.65(\mathrm{~m}$, $2 \mathrm{H}, \mathrm{Ar}-\mathrm{H}), 7.60-7.52(\mathrm{~m}, 2 \mathrm{H}, \mathrm{Ar}-\mathrm{H}), 7.38(\mathrm{~d}, 1 \mathrm{H}, \mathrm{Ar}-\mathrm{H}$, $\left.{ }^{3} \mathrm{~J}\left({ }^{1} \mathrm{H}-{ }^{1} \mathrm{H}\right)=8 \mathrm{~Hz}\right), 7.14\left(\mathrm{~d}, 2 \mathrm{H}, \mathrm{Ar}-\mathrm{H},{ }^{3}{ }^{3}\left({ }^{1} \mathrm{H}-{ }^{1} \mathrm{H}\right)=12 \mathrm{~Hz}\right)$, $7.02\left(\mathrm{~d}, 2 \mathrm{H}, \mathrm{Ar}-\mathrm{H},{ }^{3} \mathrm{~J}\left({ }^{1} \mathrm{H}-{ }^{1} \mathrm{H}\right)=12 \mathrm{~Hz}\right),{ }^{13} \mathrm{C}-\mathrm{NMR}(75$ $\left.\mathrm{MHz}, \mathrm{DMSO}-d_{6}\right): 169,151,141,134,131,130,129.6$, 129.0, 128.7, 128.2, 127.7, 127.3, 126, 123, 122, 21.

\section{3. Theoretical Methods}

The molecular modeling was performed using Gaussian 09 program package for calculations. In the present work, the calculations have been carried out at (DFT/B3LYP) method with $6-31+\mathrm{G}(\mathrm{d}, \mathrm{p})$ basis set. The vibrational frequencies of the molecules were calculated for the complete equilibrium geometry obtained by the same quantum chemical model in the gas phase. The frequency values computed at these levels contain known systematic errors and therefore, scaling factors $0.99^{24}$ and $0.98^{25}$ were used for $1700-4000 \mathrm{~cm}^{-1}$ and $400-1700 \mathrm{~cm}^{-1}$ ranges, respectively. Electron correlations were included using Becke3-Lee-Yang-Parr (B3LYP) procedure. ${ }^{26}$ This contains Becke's gradient exchange corrections, Lee, Yang and Parr correlation functional and/or Vosko, Wilk and Nusair correlation functional. ${ }^{27}$

\section{4. Anticancer Activity}

In vitro anticancer activities of the synthesized compounds (1-8) were evaluated against the human cancer lines MCF-7 (human breast adenocarcinoma) using MTT (3-(4,5-dimethylthiazol)-2-yl]-2,5-diphenyl-2 $\mathrm{H}$-tetrazolium bromide) assay. ${ }^{28}$ The assay was related with the reduction of tetrazolium salt by mitochondrial dehydrogenase of viable cells to form a blue formazan product dissolved in DMSO and measured at $570 \mathrm{~nm}$.

\section{5. Docking Studies}

AutoDock Vina package software was used to study the binding affinity of the compounds (1-8) with Brca2Dss1-Ssdna complex (BRCA2) as a target for anticancer compounds. The crystal structure of the protein was obtained from the Brookhaven Protein Data Bank (http:// www.rcsb.org/pdb) (entry code: 1MJE). Then water molecules were removed, and hydrogen atoms were added to the BRCA2 structure and the geometry of title compound was optimized using the Gaussian 09 program package. The potential energy curve (PES) of the molecule was obtained performing a relaxed scan of dihedral angles at semi empirical method PM3 level of theory. For the lowest energy conformer, the geometric structure was reoptimized at DFT level (B3LYP/6-311G+(d,p)). After these stages, the most favorable docking model was selected according to the binding energy and geometry matching that converted to the pdp format.

\section{Acknowledgement}

We are indebted to the Adiyaman University Research Foundation (FEFAAP/2012-0001) for financial support of this work. 


\section{References}

1. S. Subashchandrabose, A. R. Krishnan, H. Saleem, S. Kavitha, V. Thanikachalam, G. Manikandan, J. Mol. Struct. 2011, 996, 1-11. http://dx.doi.org/10.1016/j.molstruc.2010.12.048

2. B. S. Holla, K. N. Poojary, B. Kalluraya, P. V. Gowda, Farmaco, 1996, 51,793-799.

3. R. P. Dickinson, A. S. Bell, C. A. Hitchcock, S. Narayanaswami, S. Ray, K. Richardson, P. F. Troke, Bioorg. Med. Chem. Lett. 1996, 6, 2031-2036.

http://dx.doi.org/10.1016/0960-894X(96)00363-0

4. D .J. Sheehan, C. A. Hitchcock, C. M. Sibley, Clin. Microbiol. Rev. 1999, 12, 40-79.

5. R. S. Upadhayaya, N. Sinha, S. Jain, N. Kishore, R. Chandra, S. K. Arora, Bioorg. Med. Chem. 2004, 12, 2225-2238. http://dx.doi.org/10.1016/j.bmc.2004.02.014

6. S. N. Pandeya, D. Sriram, G. Nath, E. De Clercq, Arzneim. Forsch. Drug Res. 2000, 50, 55-59.

7. F. P. Invidiata, S. Grimaudo, P. Giammanco, L. Giammanco, Farmaco 1991, 46, 1489-1495.

8. O. G. Todoulou, A. E. Papadaki-Valiraki, E. C. Filippatos, S. Ikeda, E. De Clercq, Eur. J. Med. Chem. 1994, 29, 127-131. http://dx.doi.org/10.1016/0223-5234(94)90209-7

9. F. P. Invidiata, D. Simoni, F. Scintu, N. Pinna, Farmaco 1996, 51, 659-664.

10. G. G. Mohamed, C. M. Sharaby, Spectrochim. Acta A, 2007, 66, 949-958. http://dx.doi.org/10.1016/j.saa.2006.04.033

11. K. Singh, M. S. Barwa, P. Tyagi, Eur. J. Med. Chem. 2007, 42, 394-402.

http://dx.doi.org/10.1016/j.ejmech.2006.10.016

12. C. Alasalvar, M. S. Soylu, Y. Ünver, G. Apaydýn, D. Unluer, J. Mol. Struct. 2013, 1033, 243-252. http://dx.doi.org/10.1016/j.molstruc.2012.10.035

13. E. Schreier, Helv. Chim. Acta. 1976, 59, 585-606. http://dx.doi.org/10.1002/hlca.19760590223

14. The Merk Index; $12^{\text {th }}$ ed., Merk Co. Inc., Whitehouse Station 1996.

15. J. Haber, Cas. Lek. Cek. 2001, 140, 596-604.

16. N. L. Dias Filho, R. M. Costa, F. Marangoni, D. Souza Pereira, J. Colloid Interface Sci., 2007, 316, 250-259. http://dx.doi.org/10.1016/j.jcis.2007.07.034

17. M. Zourob, N. Goddard, J. Biosens. Bioelectron. 2005, 20, 1718-1727. http://dx.doi.org/10.1016/j.bios.2004.06.031

18. J. R. Santen, Steroids 2003, 68, 559-567. http://dx.doi.org/10.1016/S0039-128X(03)00096-5

19. M. Clemons, R. E. Colemon, S. Verma, Cancer Treat. Rev. 2004, 30, 325-332. http://dx.doi.org/10.1016/j.ctrv.2004.03.004

20. Z. K. Genc, S. Tekin, S. Sandal, M. Genc, Res. Chem. Intermed. 2015, 41, 6229-6244. http://dx.doi.org/10.1007/s11164-014-1735-1

21. Fr. Demande 1969, FR 200587019691219.

22. H. N. Dogan, S. Rollas, H. Erdeniz, Farmaco, 1998, 53, 462-467 http://dx.doi.org/10.1016/S0014-827X(98)00049-4
23. A. Duran, H. N. Dogan, Farmaco, 2002, 57, 559-564. http://dx.doi.org/10.1016/S0014-827X(02)01248-X

24. J. B. Foresman, E. Frisch, Exploring Chemistry with Electronic structure methods: A Guide to Using Gaussian, Gaussian, Pittsburgh, PA, 1993. NIST Chemistry Webbook, IR database, http://srdata.nist.gov/cccbdb.

25. A. D. Becke, J. Chem. Phys. 1993, 98, 5648-5652. http://dx.doi.org/10.1063/1.464913

26. C. Lee, W. Yang, R. G. Parr, Phys. Rev. B, 1988, 37, 785789. http://dx.doi.org/10.1103/PhysRevB.37.785

27. N. Kolocouris, G. B. Foscolos, A. Kolocouris, P. Marakos, N. Pouli, G. Fytas, S. Ikeda, E. DeClercq, J. Med. Chem. 1994, 37, 2896-2902. http://dx.doi.org/10.1021/jm00044a010

28. X.-H. Li, X.-R. Liu, X.-Z. Zhang, Spectrochim. Acta Part A, $2011,78,528-534$. http://dx.doi.org/10.1016/j.saa.2010.11.022

29. I. Fleming, Frontier Orbitals and Organic Chemical Reactions, John Wiley and Sons, New York,1976.

30. F. E. Koehn, G. T. Carter, Nat. Rev. Drug Discov. 2005, 4, 206-220. http://dx.doi.org/10.1038/nrd1657

31. A. R. Carroll, R. J. Quinn, N. B. Pham, G. K. Pierens, S. Muresan, L. Suraweera, M. E. Palframan, P. Baron, J. E. Neve, Building a drug-like natural product library; In: Congress of Drug Design Amongst the Vines; Hunter Valley, NSW, Australia, 2006.

32. A. Jarrahpour, J. Fathi, M. Mimouni, T. B. Hadda, J. Sheikh, Z. H. Chohan, Med. Chem. Res. 2011, 19, 1-7.

33. A. Rauf, F. Ahmed, A. M. Qureshi, K. A. Aziz-ur-Rehman, M. I. Qadir, M. I. Choudhary, Z. H. Chohan, M. H. Youssoufi, T. B. Hadda, J. Chin. Chem. Soc. 2011, 58, 1-10.

34. J. Sheikh, A. Parvez, V. Ingle, H. Juneja, R. Dongre, Z. H. Chohan, M. H. Youssoufi, T. B. Hadda, Eur. J. Med. Chem. 2011, 46, 1390-1399. http://dx.doi.org/10.1016/j.ejmech.2011.01.068

35. A. Parvez, M. Jyotsna, M. H. Youssoufi, T. B. Hadda, Phosphorus, Sulfur Silicon Relat. Elem. 2010, 7, 1500-1510. http://dx.doi.org/10.1080/10426500903095556

36. A. Parvez, J. Meshram, V. Tiwari, J. Sheikh, R. Dongre, M. H. Youssoufi, T. B. Hadda, Eur. J. Med. Chem. 2010, 45, 4370-4378. http://dx.doi.org/10.1016/j.ejmech.2010.06.004

37. Z. H. Chohan, M. H. Youssoufi, A. Jarrahpour, T. B. Hadda, Eur. J. Med. Chem. 2010, 45, 1189-1199. http://dx.doi.org/10.1016/j.ejmech.2009.11.029

38. A. Jarrahpour, M. Motamedifar, M. Zareil, M. H. Youssoufi, M. Mimouni Z. H. Chohan, T. B. Hadda, Phosphorus, Sulfur Silicon Relat. Elem. 2010, 185, 491-497. http://dx.doi.org/10.1080/10426500902953953

39. T. B. Hadda, M. A. Ali, M. Vasand, S. Gharby, T. Fergoug, I. Warad, Med. Chem. Res. 2013, 22, 1438-1449. http://dx.doi.org/10.1007/s00044-012-0143-6 


\section{Povzetek}

Članek opisuje sintezo derivatov 1,2,4-triazola ter njihovo uporabo v medicini, predvsem kot zdravil proti raku dojk, kar je velik problem sedanjosti. Sintetizirane spojine smo opredelili z elementarno analizo, FT-IR in NMR. DFT smo uporabili za preučevanje kvantno kemijskih izračunov geometrij in vibracijskih valovnih dolžin 3-hidroksinaftil in $p$-tolil substituiranih 1,2,4-triazolov v osnovnem stanju. Prilagojeno število harmoničnih vibracijskih frekvenc, pridobljenih z metodo DFT, smo primerjali s tistimi iz FT-IR spektrov in našli dobro ujemanje. Sintetizirane 1,2,4-triazol-naftilne hibride smo pregledali za aktivnost proti raku na MCF-7 celičnih linijah raka dojk. Med spojinami sta 3 in 7 pokazali širok spekter aktivnosti proti raku z IC50 vrednostmi $9.7 \mu \mathrm{M}$ in $7.10 \mu \mathrm{M}$, njuna aktivnost pa je primerljiva s standardnimi zdravili. Molekulski model za vezavo med spojinami (1-8) in aktivno mesto BRCA2 smo pridobili na osnovi rezultatov računalniškega sidranja in odnosom med strukturo in aktivnostjo. 